\title{
A multi-disciplinary study of Phanerozoic landscape development in West Greenland
}

\author{
Johan M. Bonow, Peter Japsen, Paul F. Green, Robert W. Wilson, James A. Chalmers, \\ Knud Erik S. Klint, Jeroen A.M. van Gool, Karna Lidmar-Bergström and Asger Ken Pedersen
}

The western margin of the Greenland craton has been much less stable in the Phanerozoic than previously thought. This new insight has come from close integration of independent data sets: geomorphological analysis of large-scale landscapes, apatite fission track analysis (AFTA), onshore and offshore stratigraphy and analysis of onshore fault and fracture systems. Each data set records specific and unique parts of the event chronology and is equally important to establish a consistent model. A key area for understanding the MesozoicCenozoic landscape evolution and into the present is the uplifted part of the Nuussuaq Basin, where remnants of planation surfaces cut across the Cretaceous to Eocene sedimentary and volcanic rocks. Our integrated analysis concluded that the West Greenland mountains were formed by late Neogene tectonic uplift (Fig. 1) and also provided new insight into early Phanerozoic development. To understand our model, we present the different methods and the results that can be deduced from them.

\section{Basic concepts}

The mapping of volcanic and sedimentary successions within the Nuussuaq Basin is crucial for understanding the late Mesozoic-Palaeogene landscape development (e.g. Dam et al. 1998; Chalmers et al. 1999; Dalhoff et al. 2003). Especially important for the landscape analysis is the availability of maps showing vertical geological sections (Pedersen et al. 2006). Exploration for hydrocarbons has resulted in many seismic data, and several deep wells have been drilled both onshore and offshore (e.g. Chalmers et al. 1999; Piasecki 2003).

Landscape analysis aims at setting up a relative tectonic event chronology through identification and mapping of both extensive baselevel governed surfaces and re-exposed surfaces. These palaeosurfaces, formed by erosion in climates or tectonic settings different from the present, cut across bedrock of different ages and can be arranged in chronological order based on (1) stratigraphical relationships with cover rocks, (2) geometrical relationships between different palaeosurfaces, and (3) analysis of the detailed forms of the largescale landscapes, reflecting climatic-driven formation processes. The baselevel is fundamental, as lowering of baselevel (an uplift event) causes valley incision and initiation of surface formation while raising baselevel (subsidence) causes palaeosurfaces to be preserved below cover rocks (Bonow 2005; Bonow et al. 2006a, b).

AFTA is a method for defining the temperature history of rock samples, based on analysis of radiation damage features ('fission tracks') produced by spontaneous fission of ${ }^{238} \mathrm{U}$ atoms within apatite crystals. Tracks are produced continu-

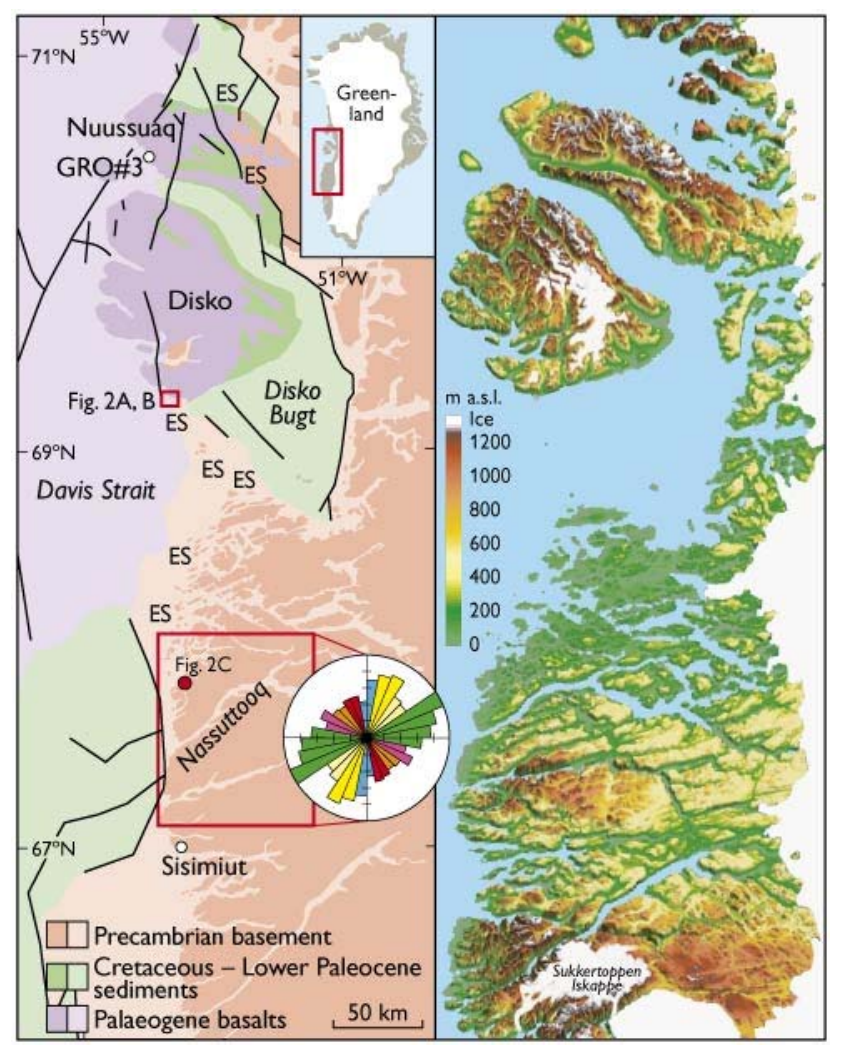

Fig. 1. Left: Study area with Precambrian basement and cover rocks that are crucial for determining the relative age of palaeosurfaces. The rose diagram summarises the regional lineament patterns, based on field mapping in the framed area (cf. Wilson et al. 2006). The relationship between lineaments onshore and offshore allows for a relative event chronology; colouring refers to timing (cf. Fig. 3). Position of GRO\#3 well indicated. ES, etch surface of Late Mesozoic - Paleocene age. Note its position close to cover rocks. Modified from Bonow et al. (2006a). Right: Topography. A regionally developed Oligocene-Miocene planation surface was differentially uplifted on separate tectonic blocks in the Neogene. Today it is close to the summit level and has been tilted in different directions. 

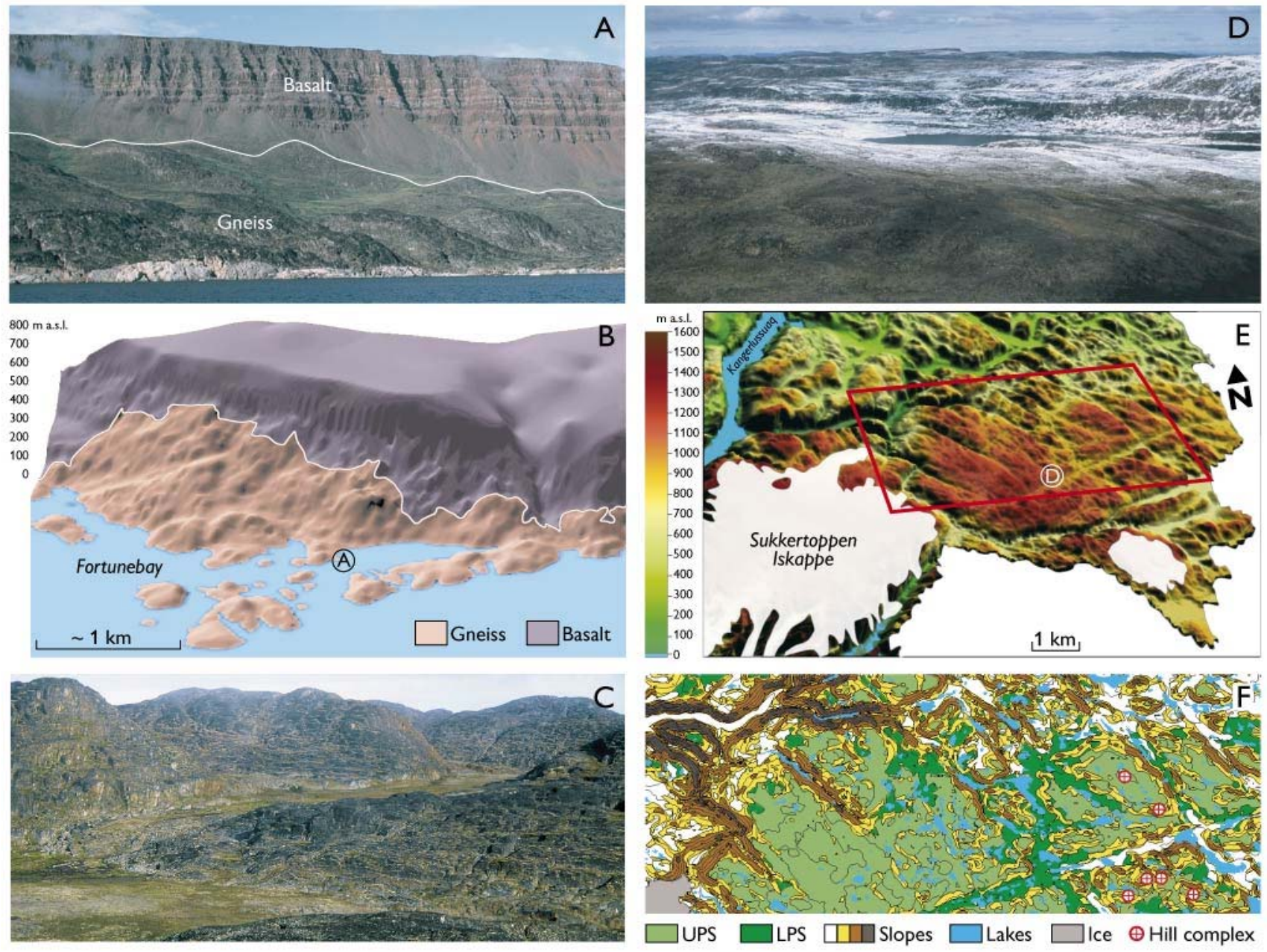

Fig. 2. Views of the etch surface (ES) and the upper and lower planation surfaces (UPS and LPS) formed in basement rocks. A: The re-exposed ES at Fortunebay, southern Disko. The white line shows the approximate border between Paleocene basalt and gneiss. Area location in Fig. 1. Photo location in B. B: 3D model of the Fortunebay area. Note the Oligocene-Miocene planation surface at high elevation across the basalt. Modified from Bonow (2005). C: The stripped ES at Nassuttooq. Location in Fig 1. D: The Oligocene-Miocene UPS east of Sukkertoppen Iskappe cuts across Precambrian basement. Location in E. E: 3D model showing the well-preserved UPS east of Sukkertoppen Iskappe. Red frame indicates position of map in F. F: Map showing UPS and LPS. Hill complexes rising above the UPS may be part of a sub-Ordovician peneplain. Modified from Bonow et al. (2006a).

ously over geological time, but are shortened at a rate that depends on the prevailing temperature, until at temperatures higher than $c .120^{\circ} \mathrm{C}$ tracks are totally erased ('annealing'). Fission track age and track length data provide the basis for estimating the time at which a sample began to cool from a palaeo-thermal maximum as well as the magnitude of the maximum palaeotemperature. Cooling can be interpreted as either change of heat-flow within the crust or erosion of overlying rocks (e.g. Green et al. 2002).

Structural analysis of faults and fracture systems aims to establish a relative chronology of tectonic movements that have changed the stress field, as a change will lead to the formation of a new set of faults and possibly the reactivation of older ones. Structural analysis of the area between Nuussuaq and Sisimiut forms the basis for a regional model, explaining different tectonic movements through time (Wilson et al. 2006).

\section{Key results}

Geology. The Cretaceous-Palaeogene sedimentary and volcanic successions within the Nuussuaq Basin record deep incision of valleys in the Maastrichtian and early Paleocene (e.g. Dam et al. 1998), subsidence during volcanism, and deposition of marine sediments within the volcanic succession now at high elevation (Piasecki et al. 1992), which are evidence that both uplift and subsidence of kilometre scale took place during and after rifting (Chalmers et al. 1999). During the Palaeogene the basalts offshore (and probably onshore, Japsen et al. 2006a) became buried below sediments. Seismic sections west of Nuussuaq show that Palaeogene and younger sequences have been tilted seawards and truncated at a late date (Chalmers 2000). 


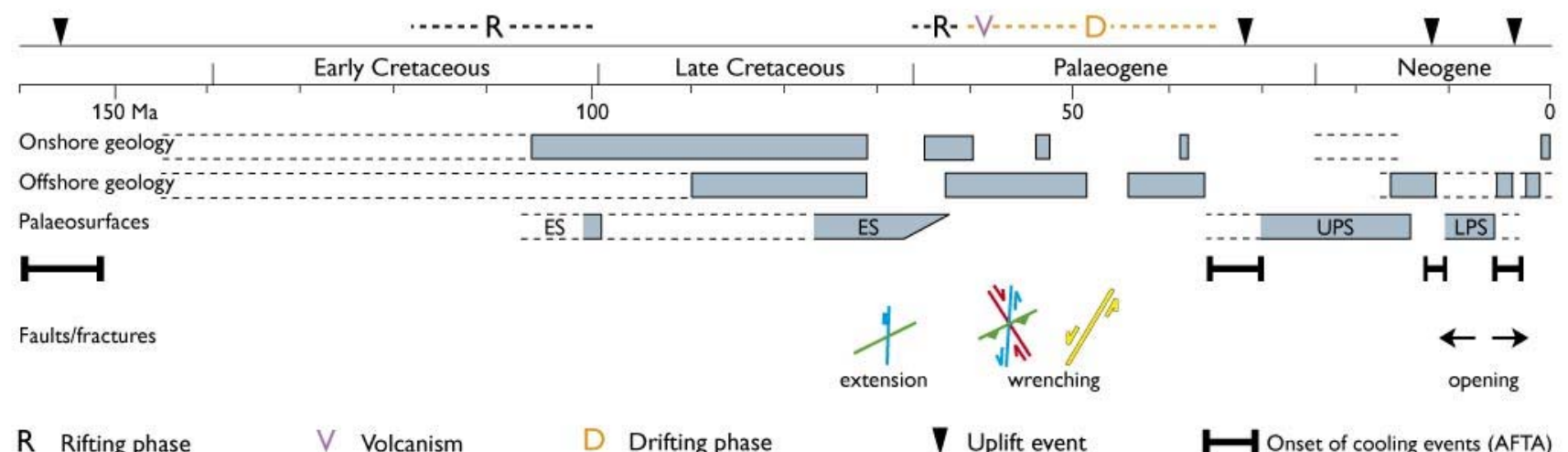

Fig. 3. Event chronology for central West Greenland based on data from the separate disciplines. Integration of these data sets shows that the western margin of the Greenland craton has been less stable than previously thought. Shaded intervals indicate the proven age of geological units, onshore and offshore, and the estimated time required for formation of palaeosurfaces. Horizontal arrows indicate extensional reactivation and opening of vertical fault and fracture systems. The associated intervals indicated by stippled lines illustrate the probable geological age range and uncertainties in dating palaeo-surfaces. ES, etch surfaces; UPS, upper planation surface; LPS, lower planation surface. Data from Piasecki et al. (1992); Dam et al. (1998); Chalmers et al. (1999); Chalmers (2000); Dalhoff et al. (2003); Piasecki (2003); Bonow (2005); Japsen et al. (2005, 2006a); Bonow et al. (2006a, b, c); Pedersen et al. (2006) and Wilson et al. (2006).

Geomorphology. Three different palaeosurfaces in the Precambrian basement have been identified in West Greenland, viz. a surface formed by deep weathering and stripping of the weathering mantle (etch surface, ES), and an upper and lower planation surface (UPS and LPS; Bonow 2005; Bonow et al. 2006a, b). The ES is characterised by distinct hills (Fig. 2A) and received its final shape in part prior to the deposition of Upper Cretaceous deltaic sediments and in part prior to the extrusion of Palaeogene basalts (Fig. 2B). The ES can mainly be identified at low elevations and close to cover rocks (Figs 1, 2C). The UPS has low relative relief compared to the ES (Fig. 2D) and must be younger as it cuts across both midEocene basalts and the etch surface. The UPS forms the summits of differentially tilted, fault-bounded tectonic blocks. A planation surface cannot be formed as an inclined plain because any tilt would cause valleys to incise and the relief to rejuvenate towards the baselevel (Bonow et al. 2006b, fig. 6). The LPS was formed in response to lowered baselevel (uplift) and became incised into the UPS (Fig. 2E). Furthermore, summits of distinct hill complexes above the UPS (Fig. 2F)

Table 1. Onset of cooling episodes determined from AFTA data

\begin{tabular}{lc}
\hline Stratigraphic age & Onset of cooling, Ma \\
\hline Cambrian / Early Ordovician & $560-500$ \\
Late Devonian / Carboniferous & $370-355$ \\
Triassic & $230-220$ \\
Late Jurassic & $160-150$ \\
Eocene-Oligocene & $36-30$ \\
Late Miocene & $11-10$ \\
Miocene-Pliocene & $7-2$ \\
\hline
\end{tabular}

From Japsen et al. (2006a) and supplementary data herein. may relate to a sub-Ordovician palaeosurface because remnants of Lower Palaeozoic rocks suggest that West Greenland may have had a long-lasting Palaeozoic cover (Bonow et al. 2006a). Consequently, erosion of Precambrian basement rocks has been limited since the early Palaeozoic, but this does not exclude deposition and subsequent removal of thick sequences of Phanerozoic cover rock as indicated by AFTA data.

Thermochronology. AFTA data from Cretaceous sedimentary rocks define three major Cenozoic cooling episodes, while basement samples define major Triassic and Jurassic cooling episodes (related to rifting?), and also earlier (Palaeozoic) episodes (Table 1). The deepest samples in the $3 \mathrm{~km}$ deep GRO\#3 well on Nuussuaq are totally annealed (Fig. 1; Japsen et al. 2005). The progressive development of fission tracks can therefore be followed through the sedimentary section, giving a rare opportunity to resolve the details of the late Cenozoic cooling history. Oligocene cooling involved both exhumation and a decrease in basal heat flow, while Miocene and Pliocene cooling episodes were dominantly related to exhumation. The two latest cooling events constrain the cooling events into the present.

Faults and fractures. Analysis of regional lineament trends shows five main systems that fit a two-stage model (Wilson $e t$ al. 2006). A system of N-S- and NNW-SSE-trending normal faults reflects the fault patterns in the Davis Strait during the Late Cretaceous to Paleocene. This system was overprinted and reactivated by strike-slip faults associated with a later NNE-SSW-trending sinistral wrench system that reflects the development of the Ungava transform system during the Eocene. 


\section{The model and future implementation}

Our model shows where in time independent constrained data exist and time-frames for uncertainties and lack of data (Fig. 3). The model shows that each discipline has long periods of no data, but when combined only few periods have no data representation at all. In particular, landscape analysis and AFTA data complement each other, because palaeosurfaces show that rock was exposed at the landsurface, whereas AFTA data indicate when and by how much a palaeosurface has been buried. This approach shows that the present summits were buried below up to $1 \mathrm{~km}$ of rocks prior to Eocene-Oligocene uplift, and that the UPS formed during the OligoceneMiocene due to stable baselevel conditions. Similarly, uplift in the late Miocene resulted in valley incision (the LPS) and tilting of the UPS. Final uplift in the ?Pliocene resulted in the present-day mountains. Late uplift reactivated and opened the fault and fracture systems, thus facilitating both weathering and the development of a coastal escarpment (Bonow $e t$ al. 2006c). Our model is also used in ongoing uplift studies in South-West Greenland (Japsen et al. 2006b).

The integration of data from geomorphology, thermochronology, geology and fault/fracture patterns to show that the present landscape of West Greenland is the result of tectonic movements throughout the Phanerozoic with significant movements also in the Neogene and even into the present (Fig. 3). The approach presented here may be applied to understand landscape development along other passive continental margins.

\section{Acknowledgements}

This work was supported by the Carlsberg Foundation, the Bureau of Minerals and Petroleum, the Danish Natural Science Research Council, the Swedish Research Council, Arktisk Station, Stiftelsen Margit Althins stipendiefond, Svenska Sällskapet för Antropologi och Geografi and John Söderbergs stiftelse.

\section{References}

Bonow, J.M. 2005: Re-exposed basement landforms in the Disko region, West Greenland - disregarded data for estimation of glacial erosion and uplift modelling. Geomorphology 72, 106-127.

Bonow, J.M., Lidmar-Bergström, K. \& Japsen, P. 2006a: Palaeosurfaces in central West Greenland as reference for identification of tectonic movements and estimation of erosion. Global and Planetary Change 50, 161-183
Bonow, J.M., Japsen, P., Lidmar-Bergström, K., Chalmers, J.A. \& Pedersen, A.K. 2006b: Cenozoic uplift of Nuussuaq and Disko, West Greenland - elevated erosion surfaces as uplift markers of a passive margin. Geomorphology 80, 325-337.

Bonow, J.M., Klint, K.E.S. \& Japsen, P. 2006c: The Nordre Isortoq Escarpment. Field report summer 2005. Danmarks og Grønlands Geologiske Undersøgelse Rapport 2006/13, 68 pp.

Chalmers, J.A. 2000: Offshore evidence for Neogene uplift in central West Greenland. Global and Planetary Change 24, 311-318.

Chalmers, J.A., Pulvertaft, C., Marcussen, C. \& Pedersen, A.K. 1999: New insight into the structure of the Nuussuaq Basin, central West Greenland. Marine and Petroleum Geology 16, 197-224.

Dalhoff, F., Chalmers, J.A., Gregersen, U., Nøhr-Hansen, H., Rasmussen, J.A. \& Sheldon, E. 2003: Mapping and facies analysis of Paleocene mid-Eocene seismic sequences, offshore southern West Greenland. Marine and Petroleum Geology 20, 935-986.

Dam, G., Larsen, M. \& Sønderholm, M. 1998: Sedimentary response to mantle plumes: implications from Paleocene onshore successions, West and East Greenland. Geology 26, 207-210.

Green, P.F., Duddy, I.R. \& Hegarty, K.A. 2002: Quantifying exhumation from apatite fission-track analysis and vitrinite reflectance data: precision, accuracy and latest results from the Atlantic margin of NW Europe. In: Doré, A.G. et al. (eds): Exhumation of the North Atlantic margin: timing, mechanisms and implications for petroleum exploration. Geological Society Special Publication (London) 196, 331-354.

Japsen, P., Green, P.F. \& Chalmers, J.A. 2005: Separation of Palaeogene and Neogene uplift on Nuussuaq, West Greenland. Journal of the Geological Society (London) 162, 299-314.

Japsen, P., Bonow, J.M., Green, P.F., Chalmers, J.A. \& Lidmar-Bergström, K. 2006a: Elevated, passive continental margins: long-term highs or Neogene uplifts? New evidence from West Greenland. Earth and Planetary Science Letters 248, 315-324.

Japsen, P., Bonow, J.M., Peulvast, J.-P. \& Wilson, R.W. 2006b: Uplift, erosion and fault reactivation in southern West and South Greenland. Field report summer 2006. Danmarks og Grønlands Geologiske Undersøgelse Rapport 2006/63, 77 pp.

Pedersen, A.K., Larsen, L.M., Pedersen, G.K. \& Dueholm, K.S. 2006: Five slices through the Nuussuaq Basin, West Greenland. Geological Survey of Denmark and Greenland Bulletin 10, 53-56.

Piasecki, S. 2003: Neogene dinoflagellate cysts from Davis Strait, offshore West Greenland. Marine and Petroleum Geology 20, 1075-1088.

Piasecki, S., Larsen, L.M., Pedersen, A.K. \& Pedersen, G.K. 1992: Palynostratigraphy of the lower Tertiary volcanics and marine clastic sediments in the southern part of the West Greenland basin: implications for the timing and duration of the volcanism. Rapport Grønlands Geologiske Undersøgelse 154, 13-31.

Wilson, R.W., Klint, K.E.S., van Gool, J.A.M., McCaffrey, K.J.W., Holdsworth, R.E. \& Chalmers, J.A. 2006: Faults and fractures in central West Greenland: on-shore expression of continental break-up and sea-floor spreading in the Labrador - Baffin Bay Sea. Geological Survey of Denmark and Greenland Bulletin 11, 185-204.

\footnotetext{
Authors' addresses

J.M.B., P.J., J.A.C., K.E.S.K. \& J.A.M.v.G., Geological Survey of Denmark and Greenland, Øster Voldgade 10, DK-1350 Copenhagen K, Denmark.

E-mail: jbon@geus.dk

P.F.G., Geotrack International, 37 Melville Road, Brunswick West, Victoria 3055, Australia.

R.W.W., Reactivation Research Group, Department of Earth Sciences, University of Durham, Durham, DH1 3LE, UK.

K.L.-B., Department of Physical Geography and Quaternary Geology, Stockholm University, SE-106 91 Stockholm, Sweden.

A.K.P., Geological Museum, University of Copenhagen, Øster Voldgade 5-7, DK-1350 Copenhagen K, Denmark.
} 